\title{
Identifying environmental risk to male reproductive function by occupational sperm studies: logistics and design options
}

\author{
Jens Peter Bonde, Aleksander Giwercman, Erik Ernst, Asclepios
}

\begin{abstract}
Malfunction of the male reproductive system might be a sensitive marker of environmental hazards, the effects of which may extend beyond reproductive function. The testis is more vulnerable to heat and ionising radiation than any other organ of the body and several xenobiotics are known to disrupt spermatogenesis

impact on human testicular function. Occupational sperm studies should probably not be the first choice when the objective is initial screening of environmental impact on fertility but should be implemented when their is a need to corroborate or refuse earlier evidence that specific exposures have impact on testicular function.
\end{abstract} after low level exposure. Studies of environmental impact on human health are often most informative and accurate when carried out in the workplace where exposures can be high and easy to document. Semen analysis provides readily obtainable information on testicular function. The main advantages in comparison with functional measures such as fertility rates and time taken to conceive are the possibilities to examine men independently of marriage and pregnancy, to find changes of fecundity with different exposures within the same person and to detect adverse effects when no alteration of fertility is yet taking place. In the implementation of an occupational sperm study considerable attention must be paid to logistic issues. A mobile laboratory unit for initial semen preparation and processing may in some situations increase worker compliance and the quality of sperm cell motility. The cross sectional design which has been used in almost all male reproductive studies so far has several severe limitations including selection bias because of differential participation, difficulties in defining a suitable reference group, and lack of information about the time dimension of the cause-effect relation. The longitudinal design deals adequately with most of these constraints. Semen samples are collected before, during, and possibly after exposure to the risk factor of interest and causal inferences are based upon change of semen variables within a man over time rather than upon differences between men. The logistics of the longitudinal study may benefit from pre-employment health examinations to enrol newly hired workers and require fewer participants to obtain comparable statistical power. In conclusion, andrological methods and epidemiological designs are available for the implementation of valid studies concerned with environmental
(Occup Environ Med 1996;53:511-519)

Keywords: male fertility; occupation; sperm study; toxicity

\section{Introduction}

Although about $15 \%$ of couples in Europe are unable to conceive within one year only limited attention has been paid to infertility in environmental research and occupational medical practice. Lack of proper research methods and limited knowledge in the field are probably among the reasons. Reduced male fecundity is involved in a major fraction of infertile cases, but most often the causes of reduced semen quality and other disturbances of male reproductive function are unknown. ${ }^{1}$ Environmental factors including workplace exposures may be of greater significance than recognised so far. ${ }^{2}$ The testis is more sensitive to radiation and radiant heat than any other tissue of the organism and limited comparable data indicate that some chemicals can impair human fecundity at exposures which do not produce detectable changes in rat spermatogenesis. ${ }^{3}$ The reserve capacity of sperm production-which can be destroyed without impairment of fecundity-is probably limited in humans compared with many other species. ${ }^{4}$ Finally, several examples of occupational exposures causing impairment of male fecundity - such as certain pesticides, metals, and solvents ${ }^{2}$-also call for additional research in this field.

Semen analysis provides readily obtainable information on quantitative and qualitative aspects of testicular function. This approach has advantages as well as limitations compared with other measures of male fecundity such as fertility rates ${ }^{56}$ and time to pregnancy. ${ }^{7}$ Among the main advantages are the possibility to examine men independently of marriage, the possibility to find changes across exposure conditions within the same person, and the possibility to detect adverse effects at an early 
stage when no alteration of fertility is yet present.

The purpose of this paper is to present and discuss the methodological advantages and limitations of environmental sperm studies and to suggest options for improvement of design and analysis. A brief outline of biological mechanisms of male reproductive toxicants, measures of semen quality, and the relation between seminal variables and fertility is a necessary introduction to the design issues.

\section{Possible mechanisms of action of factors affecting male fertility}

The normal male fecundity is a result of a complicated interplay of several mechanisms involved in production of spermatozoa as well as the transportation of the sperm from the gonads to the ejaculated semen. Thus, the hypothalamopituitary axis regulates, through the production of the gonadotrophins FSH and $\mathrm{LH}$, the function of Sertoli cells of the seminiferous epithelium and of the androgen producing Leydig cells. Additionally, the normal function of cells located outside the seminiferous tubules-Leydig cells and the so called myoepithelial cells-is necessary for maintaining normal sperm production. Furthermore, factors affecting normal function of the accessory sex glands-epididymis, prostate, and seminal vesicles - will also have influence on the fertilising potential of sperm. Prostate and seminal vesicles are highly androgen dependent but apart from this only a little is known about the physiology and pathophysiology of accessory sex glands. ${ }^{8}$ Also the process of normal erection and sperm emission and ejaculation are of crucial importance to the fecundity of the male. Psychogenic, neurogenic, and other factors are involved in these processes. ${ }^{9}$

There is, therefore, no doubt that occupational and other environmental factors may have a negative impact on male reproductive function acting by different mechanisms: (a) as hormones or antihormones interfering with the normal endocrine and paracrine regulation; (b) as toxicants destructing specific cell types such as germ cells, Sertoli cells, or Leydig cells; $(c)$ as germ cell mutagens causing production of sperm unable to fertilise or resulting in early miscarriage, malformation, or genetic disease in the offspring; $(d)$ as neurotoxic compounds disturbing normal erection, emission, or ejaculation. ${ }^{8}$

It also needs to be mentioned that not only the type of exposure but also the timing in relation to the development of the reproductive system is important for the type and magnitude of the harmful effect. The period between the 8th and the 10th gestational week seems to be critical for the development of the male gonads. ${ }^{10}$ It has been hypothesised that relatively insignificant exposures acting at this period of the prenatal life may have serious consequences for the future reproductive capability of the man. ${ }^{11}$ Thus, studies on environmental effects on male reproduction should not only focus on exposures rendered during the reproductive life, but should also include the fetal and infantile period of the development.

\section{Measures of semen quality and their biological significance in relation to fecundity}

For obvious reasons, there is an interest in defining biological variables which reflect the fecundity (biological ability to father a child) of men. Some valuable information may be extracted from clinical examination, mainly the measure of testis size and serum concentrations of sex hormones and gonadotrophins. Other laboratory tests such as sensitive urinary assay of human chorionic gonadotrophin for detection of early subclinical miscarriages may also be of relevance for occupational studies.

However, as laboratory tests for evaluation of male fecundity, the analysis of different semen variables has attracted most attention. Table 1 shows the most common semen vari-

Table 1 Standard procedures for assessment of seamen quality ${ }^{21}$

\begin{tabular}{|c|c|c|c|c|}
\hline Semen variables & Technique & Normal value & Organ dependence & Problems in relation to field studies \\
\hline Volume & Pipette, graded tube & $\geqslant 2.0 \mathrm{ml}$ & HPA, ASG, P & $\begin{array}{l}\text { Psychogenic stress implies reduction of volume; high } \\
\text { frequency of spillage, abstinence period dependent }\end{array}$ \\
\hline $\begin{array}{l}\mathrm{pH} \\
\text { Sperm density }\end{array}$ & $\begin{array}{l}\mathrm{pH} \text { paper } \\
\text { Improved Neubauer } \\
\text { haemocytometer or other } \\
\text { counting chambers }\end{array}$ & $\begin{array}{l}7 \cdot 2-8 \cdot 0 \\
\geqslant 20 \text { million } / \mathrm{ml}\end{array}$ & $\begin{array}{l}\text { ASG } \\
\text { HPA, T, ASG }\end{array}$ & $\begin{array}{l}\text { Low sensitivity } \\
\text { Result may be dependent on the type of counting } \\
\text { chamber used, variation between observers, } \\
\text { abstinence period dependent }\end{array}$ \\
\hline $\begin{array}{l}\text { Total sperm count } \\
\text { Motility: }\end{array}$ & Volume $\times$ sperm density & $\geqslant 40$ million & HPA, T, ASG, P & $\begin{array}{l}\text { As for volume and density } \\
\text { Sensitive for variations in sampling technique and } \\
\text { laboratory conditions (duration of abstinence, lag } \\
\text { period from ejaculation to analysis, temperature }\end{array}$ \\
\hline Grade $a-b-c-d$ & $\begin{array}{l}\text { Microscopical examination of a } \\
\text { fresh drop of ejaculate }\end{array}$ & $\begin{array}{l}a+b \geqslant 50 \% \text { or } \\
a \geqslant 25 \%\end{array}$ & $\mathrm{~T}, \mathrm{ASG}$ & $\begin{array}{l}\text { Rather subjective with high variation between } \\
\text { observers }\end{array}$ \\
\hline Penetration & $\begin{array}{l}\text { Migration distance and density } \\
\text { of sperms penetrating for } \\
\text { one hour along a capillary } \\
\text { tube filled with cervical } \\
\text { mucus or egg white }\end{array}$ & $\begin{array}{l}\text { Score system with a } \\
\text { rank scale }\end{array}$ & $\mathrm{T}, \mathrm{ASG}$ & $\begin{array}{l}\text { Time consuming, requires special equipment, as for } \\
\text { motility in general }\end{array}$ \\
\hline CASA & $\begin{array}{l}\text { Computer assisted analysis } \\
\text { of sperm motility (fresh } \\
\text { preparation or video tapes) }\end{array}$ & $\begin{array}{l}\text { No accepted normal } \\
\text { values }\end{array}$ & T, ASG & $\begin{array}{l}\text { Equipment requirements, results dependent on } \\
\text { chamber type, as for motility in general }\end{array}$ \\
\hline $\begin{array}{l}\text { Vitality } \\
\text { Morphology: }\end{array}$ & Staining of fresh drop of semen & $\geqslant 75 \%$ live & T, ASG & \\
\hline WHO criteria & $\begin{array}{l}\text { Microscopic examination of } \\
\text { stained smears }\end{array}$ & $\geqslant 30 \%$ & $\mathrm{~T}, \mathrm{ASG}$ & $\begin{array}{l}\text { Large variation between observers } \\
\text { As for morphology in general }\end{array}$ \\
\hline Strict criteria ${ }^{24}$ & $\begin{array}{l}\text { Microscopic examination of } \\
\text { smears }\end{array}$ & $\geqslant 4 \%$ & T, ASG & As for morphology in general \\
\hline
\end{tabular}

HPA = hypothalamopituitary axis; $\mathrm{T}=$ testis (including different testicular cell types); ASG = accessory sex glands (epididymis, vas deferens, seminal vesicles, prostate); $\mathrm{P}=$ psychogenic factors. 
Table 2 Additional semen tests for evaluation of male reproductive function

\begin{tabular}{|c|c|c|}
\hline Semen variable & Technique & Indicator of \\
\hline Zone-free hamster oocyte test & $\begin{array}{l}\text { Assessment of mean number of spermatozoa incorporated per } \\
\text { hamster oocyte }\end{array}$ & Sperm function \\
\hline Zona pellucida binding test & $\begin{array}{l}\text { Comparison of test and control spermatozoa in relation to binding on } \\
\text { each matching half of the human zona }\end{array}$ & Binding of spermatozoa to zona pellucida \\
\hline $\begin{array}{l}\text { Acrosome reaction scoring } \\
\text { Hypo-osmotic swelling test } \\
\text { Reactive oxygen species test } \\
\text { FISH }\end{array}$ & $\begin{array}{l}\text { Fluorescent staining } \\
\text { Fresh semen mixed with hypo-osmotic buffer } \\
\text { Measurement of chemiluminescence in sperm preparation } \\
\text { Fluorescent in situ hybridisation }\end{array}$ & $\begin{array}{l}\text { Acrosomal status of spermatozoa } \\
\text { Functional integrity of sperm membrane } \\
\text { Sperm function } \\
\text { Numerical and structural chromosomal } \\
\text { abnormalities }\end{array}$ \\
\hline $\begin{array}{l}\text { Sperm chromatin structure } \\
\text { Citric acid } \\
\text { Acid phosphatase } \\
\text { Prostate specific antigen } \\
\gamma \text {-Glutamyl transpeptidase }\end{array}$ & $\begin{array}{l}\text { Flow-cytometric measurement of native: denaturated DNA ratio } \\
\text { Biochemical assay }\end{array}$ & $\begin{array}{l}\text { Changes in sperm chromatin conformation } \\
\text { Epididymal function }\end{array}$ \\
\hline $\begin{array}{l}\text { Fructose } \\
\text { Prostaglandins }\end{array}$ & Biochemical assay & Seminal vesicle function \\
\hline $\begin{array}{l}\text { Free L-carnitine } \\
\text { Glycerophosphocholine } \\
\alpha \text {-Glucosidase }\end{array}$ & Biochemical assay & Prostatic function \\
\hline
\end{tabular}

ables investigated. It needs to be mentioned that in general, our knowledge on the correlation between semen quality and male fecundity is restricted by the fact that the vast majority of the studies are based on material collected in infertility clinics and only a few studies consider the relation between semen quality and fertility of men in the general population. This may be one of the reasons why the data concerning the value of different semen variables for predicting fertility are conflicting. ${ }^{12-14}$ Thus, in some studies sperm density was found to be a good predictor of fertility whereas other studies pointed to motility or morphology as being more significant for prediction of fertility. ${ }^{12-14}$ Although the sperm density of $20 \mathrm{million} / \mathrm{ml}$ is considered to be the lowest normal value, sperm counts below $5 \mathrm{million} / \mathrm{ml}$ were reported in some men who have fathered two or more children. ${ }^{15}$ Furthermore, concentration, motility, and morphology are related to each other as factors that cause deterioration of one of them usually also have a negative impact on the other two. ${ }^{15}$

To establish better methods for assessment of male reproductive function many other techniques have been introduced. One of the methods attracting most attention is computer assisted semen analysis (CASA). The CASA systems were originally developed to make the evaluation of sperm movements more objective and accurate. Recently software for evaluation of sperm morphology has become available. Most studies correlating CASA variables to fertility outcomes are based on investigation of patients from infertility clinics. ${ }^{16}{ }^{17}$ In some of the studies it has been possible to show that CASA may be of value in prediction of pregnancy, either obtained spontaneously ${ }^{17}$

Table 3 Estimates of variation within and between laboratories in assessment of the most common semen variables ${ }^{22} 23$

\begin{tabular}{lll}
\hline Semen variable & $\begin{array}{l}\text { Coefficient of variation within } \\
\text { laboratories (\%) }\end{array}$ & $\begin{array}{l}\text { Coefficient of variation between } \\
\text { laboratories (\%) }\end{array}$ \\
\hline Concentration & 6 & $37 \cdot 5^{\star}$ \\
Morphology & 15 (overall) & 25 (normal heads) \\
& $\begin{array}{l}6 \text { (morphological forms which are } \\
\text { exceeding 20\% of all sperms) }\end{array}$ & 87 (abnormal midpieces) \\
Motility & $\begin{array}{l}29 \text { (overall) } \\
6 \text { (motility types which are } \\
\text { exceeding 20\% of all sperms) }\end{array}$ & 9 (for immotile sperms) \\
& & $25-37$ (for categories a, b, c $\dagger$ )
\end{tabular}

* Mean value (range: $23 \%$ for high to $73 \%$ for very low concentrations)

$\mathrm{ta}, \mathrm{b}, \mathrm{c}=3$ types of sperm motility ranging from normal progressive to non-progressive sluggish. or with the use of assisted reproduction. ${ }^{18}$ However, there is still a lack of information on the value of CASA as a marker of fecundity. Another major problem is lack of standardisation between different CASA systems including measurement conditions (chamber type, duration of measurement period, dilution of semen, etc). ${ }^{19}$ As it can be expected that a further development of CASA systems will take place in the near future, it is advised that video tapes of fresh semen samples are recorded, when performing occupational sperm studies. Such tapes may be investigated with already existing systems and may become even more valuable in the future, when more information on the biological significance of different CASA variables become available. Table 2 shows some of the new techniques. Generally, more research is needed to define the value of these methods for assessment of male fecundity. On the other hand, although the different biological assays may not be predictive for the fecundity of the male they still may reflect the function of the reproductive system and thereby be useful as indicators of occupational hazards to male reproduction and maybe even cellular damage in general.

A significant factor creating difficulties for the interpretation of studies concerning semen quality is the great variation in some semen variables-in particular, ejaculate volume, sperm density, and motility. The fluctuations within a man are nearly as great as the variation between men and can only partly be explained by the duration of the period of abstinence. For yet unknown reasons, the concentration and probably also the sperm motility seem to be subject to seasonal variation, with best quality being registered during the winter and spring in the northern hemisphere. ${ }^{20}$ Seasonal variation, however, accounts only for a part of the total variation, which, thus, remains largely unexplained.

Another factor adding to the confusion in the interpretation of assessment of semen quality is the enormous variation in methodology between the different laboratories. Currently, based on the guidelines of a working group under the World Health Organisation special programme of research, development, and research training in human reproduction, efforts have been made to introduce standardisation and quality control in 
Mobile sperm laboratory: van with phase-contrast microscope, camera, video recorder, heating box with thermostat, air conditioning thermostat, air conditioning
and freezer/dry ice device.

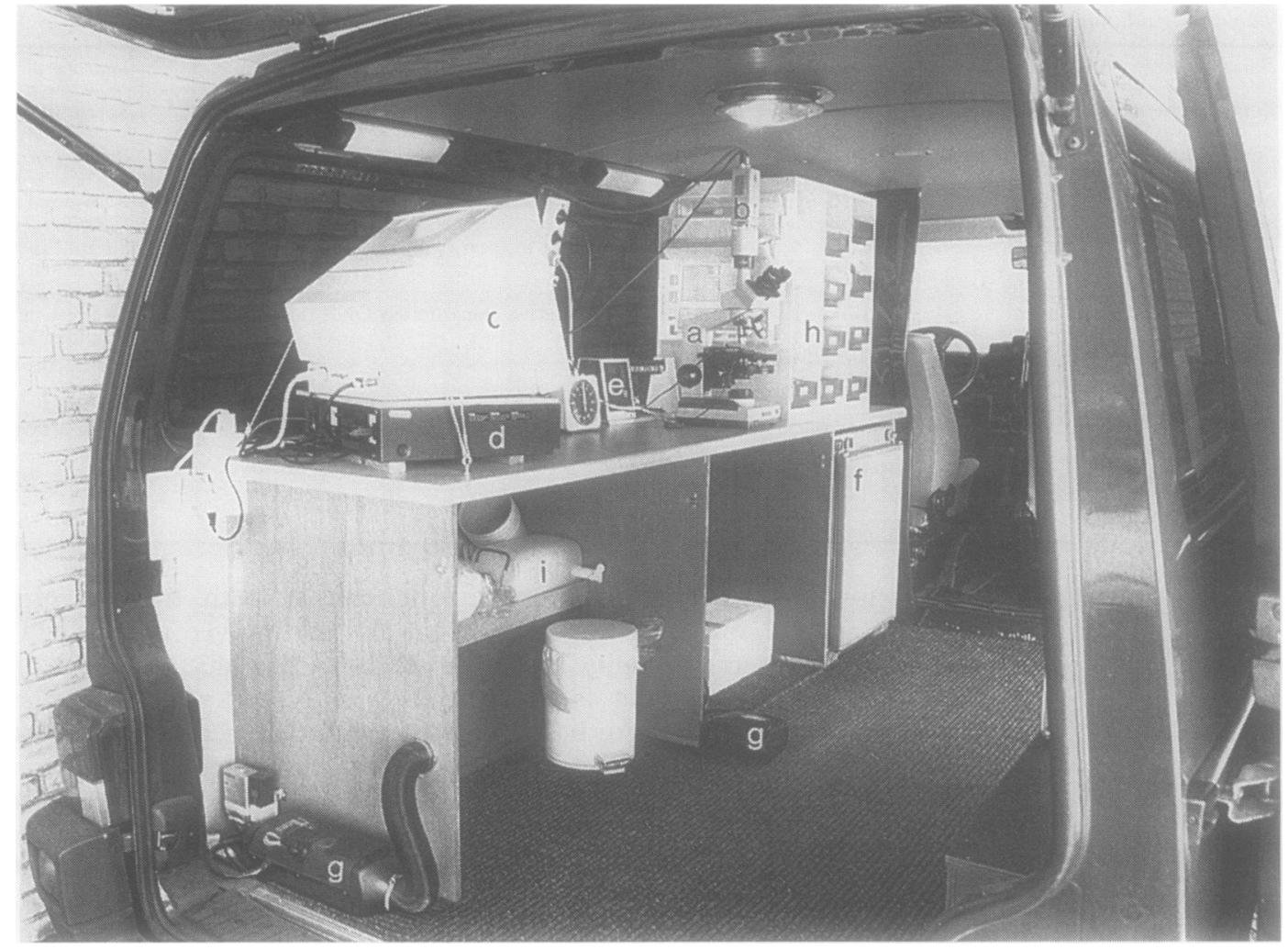

sperm laboratory work. ${ }^{21}$ Table 3 shows the magnitude of variation within and between laboratories for some of the most common semen variables. As the assessment of semen quality - even within the same laboratorymay be subject to variation between technicians and related to time, ${ }^{22}$ a continuous quality control should be performed. This issue is even more relevant if data obtained in different laboratories are pooled. In such cases an external, coordinated quality control procedure is highly recommended. ${ }^{23}$

\section{Logistics of field studies}

Semen analysis has for decades been the corner stone in the andrological evaluation of the male partner of infertile couples throughout the world. ${ }^{24}$ Although religious and personal attitudes towards sexual behavior may be incompatible with the collection of semen samples-for instance, in some catholic communities - the conduct of occupational sperm studies in populations spanning different cultural and ethnic groups in developing as well as developed countries indicate that, basically, it is feasible to carry out population based sperm studies. ${ }^{2}$ Nevertheless, the logistics of

Table 4 Participation rates in selected occupational cross sectional sperm studies from the past decade

\begin{tabular}{llllllll}
\hline & \multicolumn{3}{l}{ Participation rate (\%) } & & \\
\cline { 2 - 5 } Population & \multicolumn{2}{l}{$\begin{array}{l}\text { Exposed } \\
n\end{array}$} & $(\%)$ & $\begin{array}{l}\text { Controls } \\
n\end{array}$ & $(\%)$ & $\begin{array}{l}\text { Publication } \\
\text { year }\end{array}$ & Reference \\
\hline Petroleum refinery workers & 42 & $(68)$ & 74 & $(44)$ & 1985 & 27 \\
Papaya workers & 46 & $(64)$ & 43 & $(50)$ & 1987 & 28 \\
Shipyard painters & 73 & $(50)$ & 40 & $(32)$ & 1988 & 29 \\
Foundry workers & 37 & $(50)$ & 39 & $(26)$ & 1989 & 30 \\
Metal workers & 71 & $(37)$ & 54 & $(37)$ & 1990 & 31 \\
Ceramics industry workers & 42 & $(50)$ & 14 & $(16)$ & 1992 & 32 \\
Viscose rayon workers & 45 & $(39)$ & 35 & $(44)$ & 1994 & 33 \\
\hline
\end{tabular}

an occupational sperm study must account for the intimate nature of the topic in the way participants are approached, informed, recruited, and in the way semen samples are collected. The participants must be confident that not but even the providing of semen samples are kept confidential.

Semen samples should be obtained by masturbation rather than by interrupted intercourse to standardise the collection procedure as much as possible. It seems that some seminal variables are influenced by the method of semen collection. ${ }^{8} \mathrm{~A}$ feasible approach is asking men to produce the semen sample at home. Spillage is probably not unusual and must be recorded to allow valid data analysis of semen volume, sperm concentration, and total sperm count. The study design must account for the significance of the period of sexual abstinence. ${ }^{25}$ In andrological practice men are ask to provide the semen sample between two and five days after the last ejaculation. ${ }^{21}$ This approach is not entirely satisfactory in research because the sperm count is significantly lower two than five days after the last ejaculation. On the other hand it is not realistic to ask people to provide a sample following a fixed interval of sexual abstinence. The best compromise may be to ask for a sample after preferably two to five days of sexual continence at the same time emphasising, firstly, the importance of recording the exact and true abstinence period and, secondly, that abstinence periods outside the recommended interval is not invalidating the use of the sample for the purpose of the study. With correctly recorded abstinence periods it is possible to adjust the results in data analysis, discussed later. only the results of the individual semen analysis 
Table 5 Differential selection of volunteers participating in an occupational sperm study $4^{43}$

\begin{tabular}{|c|c|c|c|c|c|c|}
\hline \multirow[b]{2}{*}{ Characteristic } & \multicolumn{3}{|c|}{ Exposed workers } & \multicolumn{3}{|l|}{ Controls } \\
\hline & $\begin{array}{l}+ \text { Semen } \\
\text { samples } \\
n=149 \\
(\%)\end{array}$ & $\begin{array}{l}\text { - Semen } \\
\text { samples } \\
n=250 \\
(\%)\end{array}$ & $\begin{array}{l}\text { Odds ratio } \\
(95 \% \text { CI) }\end{array}$ & $\begin{array}{l}+ \text { Semen } \\
\text { samples } \\
n=79 \\
(\%)\end{array}$ & $\begin{array}{l}\text { - Semen } \\
\text { samples } \\
n=147 \\
(\%)\end{array}$ & $\begin{array}{l}\text { Odds ratio } \\
\text { (95\% CI) }\end{array}$ \\
\hline $\begin{array}{l}\text { Reduced semen quality } \\
\text { Ever fertility problem } \dagger \\
\text { Urogenital disorder } \ddagger\end{array}$ & $\begin{array}{r}3 \\
13 \\
5\end{array}$ & $\begin{array}{l}2 \\
6 \\
5\end{array}$ & $\begin{array}{l}1.4(0.3 \text { to } 5 \cdot 1) \\
2 \cdot 3(1.1 \text { to } 4 \cdot 7) \\
1.0(0.4 \text { to } 2 \cdot 4)\end{array}$ & $\begin{array}{r}8 \\
20 \\
12\end{array}$ & $\begin{array}{l}2 \\
7 \\
4\end{array}$ & $\begin{array}{l}4.2(1.4 \text { to } 3.6) \\
3.6(1.5 \text { to } 8.3) \\
3.2(1.4 \text { to } 13.6)\end{array}$ \\
\hline
\end{tabular}

^Result of semen analysis performed before and independently of the study.

†Period with inability to conceive within two years with regular intercourse.

$\$$ Maldescensus testis, orchitis, varicocele, hydrocele, abscess in scrotum.

One main constraint of a population based sperm study is the requirement to process and examine the sample within two hours to obtain valid measurements of sperm motility. ${ }^{26}$ Usually an andrological unit or a sperm research laboratory will not be within one hour's distance of the workplace or worker's home. This problem may be solved by a setting up a temporary laboratory at the workplace or by equipping a mobile unit (figure), where the initial processing of the sample is conducted within two hours of ejaculation. Further analysis takes place at the specialised laboratory.

The use of seminal variables as biological markers of male fecundity in occupational health research is beset with ethical problems also known from other research fields. One particular problem is unrecognised azoospermia which can be expected to show up in $1 \%-2 \%$ of an unselected male population and for which no medical treatment can be offered in most cases. The participants in a study should not automatically be informed about the results of the semen analysis but should be told-before providing the sample-that there is a small chance that a condition incompatible with the fathering of a child might be found by the examination and given this information the participant must actively himself decide whether he wants to be informed about the result of the semen analysis. This is particularly important if his partner is pregnant or has recently had a baby.

\section{Design options}

CROSS SECTIONAL STUDIES

The discovery in 1977 of the severe spermatotoxic action of the nematocide dibromochloropropan (DBCP) among workers at a chemical plant initiated several studies of occupational risk to male reproductive function. ${ }^{2}$ With few exceptions all studies comparing the distributions of seminal variables in an exposed population with those of an unexposed reference population were cross sectional. The participation rates were seldom above $70 \%$ and their was a uniform tendency towards lower partici-

Table 6 Participation in an occupational sperm study on age ${ }^{43}$

\begin{tabular}{llll}
\hline Age group $(y)$ & Men agreeing $n(\%)$ & Men refusing $n(\%)$ & Men with vasectomy $n(\%)$ \\
\hline $20-29$ & $87(44)$ & $113(56)$ & 0 \\
$30-39$ & $76(43)$ & $91(52)$ & $9(5)$ \\
$40-49$ & $50(27)$ & $101(55)$ & $33(18)$ \\
$\geqslant 50$ & $15(13)$ & $92(82)$ & $5(5)$ \\
\hline
\end{tabular}

pation rates among controls (table 4 ). The possibility that the men available for study may not truly reflect the parent population is a matter of concern. In particular a low participation rate would seriously interfere with the internal validity of a cross sectional study if differential selection took place depending on factors related to semen quality. This did indeed occur in a Danish study of metal welders. ${ }^{34}$ Men who agreed to provide semen samples more often had earlier knowledge that their semen quality was reduced-for instance from an earlier andrological examinationthan men who refused to participate. This differential selection was much more pronounced among controls than among exposed men (table 5). Also the association between participation and a history of urogenital disorder was stronger among controls than among exposed men in this study. These findings may not be common to all occupational sperm studies, but nevertheless they show the limitations of the cross sectional design for deriving causal inferences.

Due to seasonal variation in sperm count, the collection of samples in exposed and control men needs to take place concomitantly and possible differences in semen quality between men in urban and rural areas, which are not yet verified, need also to be taken into consideration.

It may be possible to obtain a higher participation in cross sectional studies by carefully informing and motivating workers and by limiting the age of the study population (table 6). However, this approach may prevent identification of interaction between exposure and age and effects resulting from long term cumulative exposure. Because the ranges of several seminal variables within a man are of the same magnitude as the ranges between men there is little advantage in asking for more than one semen sample per man in cross sectional studies if enough subjects are available for study. ${ }^{35-37}$ The cross sectional design, however, is burdened by several other limitations. Sperm studies share the problems of identification of a suitable reference group with other occupational studies of this type. The normal distributions of seminal variables are non-existent for large random population samples investigated with well defined and validated methods. Published series of seminal distributions in fertile men ${ }^{38} 39$ and men attending examination at infertility clinics ${ }^{40}$ are expected to be more and less fertile, respectively, than a random population sample and differences in 
abstinence periods and analytical methods invalidate use of such values for reference. When a cross sectional design shows small differences between exposed and control men it is always of concern whether the findings should be interpreted as higher than average values in the one group or lower than average values in the other group. This, together with the trivial fact that the time dimension of the cause effect relation is completely hidden in the cross sectional approach, calls for more valid designs.

\section{LONGITUDINAL STUDIES}

Design

The longitudinal design option is a rational answer to several of the main problems inherent in the cross sectional approach. Semen samples are collected before, during, and possibly after exposure to the risk factor of interest. Causal inference is based upon relative or absolute change of semen values over time within rather than between men. The spermatogenic cycle spanning the initial proliferation of spermatogonia and the final release of fully mature motile spermatozoa takes about 74 days in humans. Accordingly the effects of chemical or physical exposures acting on the early stages of spermatogenesis is detectable in the ejaculate after a delay of at least two to three months whereas effects of agents acting on the late stages of spermatogenesis or on epididymal function may show up in the ejaculate after a few days of exposure if not immediately. ${ }^{2}$ Clinical trials of spermatotoxic effects of drugs give some guidance on how the time schedule for follow up samples during exposure should be designed. ${ }^{41} \mathrm{~A}$ detailed protocol for longitudinal occupational sperm studies has been developed within the context of an ongoing European concerted action (the Asclepios project: occupational hazards to male reproductive capability).

If it is possible to achieve a significant reduction of a potential spermatotoxic exposure at the workplace, repeated sampling of semen during and after the period of change in work conditions would enable a longitudinal analysis of the relation between exposure and male reproductive function..$^{42} 43$ The work force might be highly motivated to participate in this type of reversed longitudinal study because of the inherent improvement of working conditions. The main scientific limitation is the underlying assumption that spermatogenesis-if suppressed-will return to normal within a short time after reduction of exposure. In particular this approach is not to be used in studies dealing with substances that accumulate in the body.

\section{Controls}

In principle the longitudinal design comparing changes within subjects does not render a reference group of non-exposed workers superfluous. Temporal shifts in seminal variables may occur because of seasonal variation, ${ }^{2044}$ local epidemics of infections, or because of yet unknown ${ }^{43}$ or random effects. If it is possible to document a significant contrast of exposure within the exposed study population the men with low exposure may adequately serve as controls for those with high exposure. Also the seasonal variation of seminal variables may be accounted for by collecting follow up samples with intervals of 12 months.

\section{Implementation}

It is more difficult to organise and implement a longitudinal study in spite of the lower number of participants required to achieve comparable statistical power (discussed later). However, when the occupational exposure of interest is seasonal-as for instance exposure to fungicides among potato farmers during the summer period-it is possible to recruit and sample a sufficient number of workers during short time periods before and then after the season. If the period of exposure is shorter than the spermatogenic cycle perhaps additional semen samples should be collected after the session of exposure to detect effects on the early stages of spermatogenesis. When the exposure of interest is not seasonal, the implementation of the longitudinal design relies on a sufficient turnover of the workforce to enable the enrolment of newly hired workers. This may be difficult during periods of economic recession or decline of the industry of interest. Pre-employment health examinations, training courses, or schools for apprentices may constitute the organisational framework for recruitment of newly hired workers. Alternatively the on site occupational health service or production manager might report the hiring of new workers directly to the research team.

\section{Validity}

Although the worker participation may be low in a longitudinal study requesting that each man provide several semen samples, this does not affect the internal validity. If the participating subgroups of workers are more or less vulnerable to the possible spermatotoxic actions of the exposure of interest this has bearings on the external validity. If for instance subfertile men are more likely to participate and subfertility is associated with increased vulnerability to reproductive toxicants the results of a longitudinal study might lead to an overestimation of the impact of exposure in the general work force. From both a scientific and a public health point of view the validity of the cause effect relation itself often has higher priority than external validity.

\section{Dropout}

In longitudinal studies a proportion of enrolled participants are expected to be lost to follow up for one reason or another. Although it is important to account for this when planning the dimensions of the study the drop outs will not bias the causal inference unless dropping out is dependent on change of semen quality in a systematic way. This is unlikely if results are only communicated to participants after the end of the study. 
Table 7 Potential confounders to take into consideration in design and analysis of occupational sperm studies

\begin{tabular}{|c|c|c|}
\hline Characteristic & Effect & Remark \\
\hline $\begin{array}{l}\text { Semen sample related: } \\
\text { Spillage during collection of sample }\end{array}$ & $\begin{array}{l}\text { Reduced semen volume and count and biased } \\
\text { estimate of sperm concentration }\end{array}$ & \\
\hline Sexual continence & $\begin{array}{l}\text { Volume, concentration, and total count increased } \\
\text { with increasing period of abstinence }\end{array}$ & $\begin{array}{l}\text { Sperm concentration increase } 10 \text { million } / \text { day } \\
\text { when the abstinence increase from one to seven } \\
\text { days in men with mean sperm concentration } 90 \\
\text { million } / \mathrm{ml}^{25} \text { and } 4.5 \text { million } / \text { day in men with mean } \\
\text { sperm concentration of } 55 \text { million } / \mathrm{ml}^{31}\end{array}$ \\
\hline High fever $\left(>38^{\circ} \mathrm{C}\right)$ & Suppression of spermatogenesis & May act over a period of up to six months ${ }^{21}$ \\
\hline Lag period from ejaculation to analysis & $\begin{array}{l}\text { After completed liquefaction sperm motility decreased } \\
\text { with increase of time lag }\end{array}$ & $\begin{array}{l}\text { Temperature modified the relation between } \\
\text { time lag and motility }\end{array}$ \\
\hline \multicolumn{3}{|c|}{ 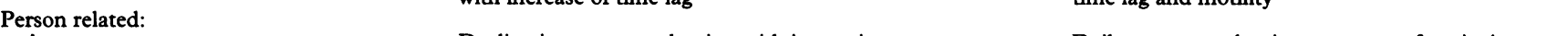 } \\
\hline Age & Decline in sperm production with increasing age & $\begin{array}{l}\text { Daily sperm production per gram of testis tissue } \\
\text { was about } 30 \% \text { higher in younger }(21-50) \text { than in } \\
\text { older }(51-80) \text { men }^{49}\end{array}$ \\
\hline Season & $\begin{array}{l}\text { Sperm concentration, volume, and proportion of sperm } \\
\text { cells higher in winter than in summer }{ }^{20}\end{array}$ & \\
\hline Smoking & $\begin{array}{l}\text { Smokers have } 10 \%-15 \% \text { lower sperm count than } \\
\text { non-smokers }\end{array}$ & $\begin{array}{l}\text { Nicotine has been suggested as the causative agent. } \\
\text { Marihuana smoking has also been reported to } \\
\text { impair testicular function }\end{array}$ \\
\hline Excessive alcohol intake & $\begin{array}{l}\text { Interfere with spermatogenesis and reduce sexual } \\
\text { function through inhibition of testosterone synthesis }\end{array}$ & $\begin{array}{l}\text { Effects of small and moderate alcohol consumption } \\
\text { is unknown }\end{array}$ \\
\hline Radiant heat & $\begin{array}{l}\text { Short term heat exposure may cause a substantial } \\
\text { reversible decrease of sperm count with about five } \\
\text { weeks delay }{ }^{2}\end{array}$ & $\begin{array}{l}\text { Effects of hot baths, close fitting underwear, and } \\
\text { sedentary activities are uncertain }\end{array}$ \\
\hline Sexually transmitted disease & $\begin{array}{l}\text { Epididymal infection causing obstruction of the genital } \\
\text { duct system }\end{array}$ & \\
\hline Urogenital disorders & $\begin{array}{l}\text { Testicular maldescent, cancer, hypospadia, varicocele, } \\
\text { testicular torsion and mumps orchitis cause reduced } \\
\text { semen quality }\end{array}$ & \\
\hline Cytotoxic drugs and irradiation & Dose dependent effects on spermatogenesis & $\begin{array}{l}\text { Permanent azoospermia after doses exceeding 4-6 } \\
\text { Gray }\end{array}$ \\
\hline Medicine & $\begin{array}{l}\text { Sulphasalazine, colchicine, niradozole, nitrofurantoin, } \\
\text { cimetidine, spironolactone, anabolic steriods, antiandrogens, } \\
\text { progestagens, oestrogens and LHRH agonists suppress } \\
\text { spermatogenesis }\end{array}$ & Effects most often reversible \\
\hline General anaesthesia & Temporary depression of fertility ${ }^{21}$ & \\
\hline History of surgery in urogenital region & $\begin{array}{l}\text { Disorders of ejaculation following prostatectomy, bladder } \\
\text { neck incision, treatment of urethral valves and strictures }{ }^{21}\end{array}$ & \\
\hline $\begin{array}{l}\text { Hernia surgical repair } \\
\text { Retroperitoneal surgery }\end{array}$ & Damage of vas deferens ${ }^{21}$ & \\
\hline & & \\
\hline
\end{tabular}

solution to the main limitations of the cross sectional design there are several methodological issues common to both approaches.

The great variability of in particular sperm count and motility reflects imprecision of the measurements, variation between observers, different frequency and efficiency of ejaculation, and fluctuations in the activity of the germinal epithelium. Imprecision of measurement and variation between observers can be reduced by implementing good laboratory practice and by computerised methods for objective assessments of sperm motility. The part of the variation of sperm count which is due to variability in the sampling procedurethe process of ejaculation-can be diminished but not eliminated by using a sample obtained after three to six ejaculations daily for three days. ${ }^{45}$ This procedure eliminates spermatozoa resident in the genital duct systems and in the ampulla and the result is more stable values reflecting the spermatogenesis. This protocol is, however, impossible to implement in an occupational field study. On the other hand it is unlikely that this source of variation can be related to exposure and the most realistic solution to this problem for the time being is the creation of a study population of a sufficient size. In this context it is interesing that it may become possible to identify biochemical markers of Sertoli cells and germ cell function in seminal fluid or blood. ${ }^{46}$

If male reproductive toxicity is associated with diminished libido or impotence it may be impossible to obtain semen samples from the men most severely affected by the harmful exposure. This matter is of concern because some substances may interfere with reproductive function through central nervous or neuroendocrine mechanisms-for instance organic solvents and lead. ${ }^{47} 48$ To be able to assess the significance of this problem information about libido and impotence should be gathered from all eligible men who are invited to participate-whether or not they actually become enrolled.

The testicular function of men who have had a vasectomy cannot be ascertained from semen analysis. This potential source of bias can be circumvented by restricting the study population to the younger age ranges where vasectomy is uncommon.

The extraneous determinants which must be accounted for in study design or analysis include personal and semen sample characteristics (table 7). In the longitudinal design the personal characteristics are only potentially confounding the results if the characteristic is changed during the follow up period-for instance that a smoker becomes an ex-smoker. If stable during follow up extraneous determinants may have significance as modifiers rather than confounders of the basic relation.

\section{Statistical analysis and power}

Table 8 shows the results of statistical power calculations to estimate the number of workers to be enrolled in cross sectional and longitudinal studies. The calculations are based on the simple methods suggested by Pocock ${ }^{53}$ with estimates of SDs within and between men derived from a series of Danish studies. ${ }^{31} 43$

The statistical analysis of sperm data is 
Table 8 Estimates of the minimal number of participants to be examined in each exposure group in order to detect $25 \%$ change of seminal characteristics with $80 \%$ probability at the 5\% significance level (mean values, between and within subject SDs taken from $^{3143}$

\begin{tabular}{lcc}
\hline Seminal characteristic & Cross sectional design & Longitudinal design \\
\hline Semen volume & 65 & 45 \\
Sperm concentration & 65 & 50 \\
Total sperm count & 110 & 100 \\
Proportion normal cells & 20 & 10 \\
\hline
\end{tabular}

Transformation of original data to obtain normality: natural logarithmic (volume), square root (concentration), cubic root (total count), logit (\% normal). Differences between samples from the same participant were normally distributed.

complicated by the fact that none of the seminal characteristics can be expected to follow a normal distribution. The distributions of sperm count, semen volume, and sperm concentration are strongly skewed towards the left with SDs proportional to the mean values. Accordingly appropriate mathematical transformations to obtain equality of variance and normal distributions are mandatory for the examination of differences between and within groups by standard parametric methods also including multivariate least square linear regression. The logarithmic function and power transformations of the form $y=x^{p}(P$ $=0.5,0.3$, or 0.1$)$ has proved to be suitable in earlier studies. ${ }^{25} 3454$ Morphology and motility scores expressed in percentages may be transformed by the logit or the arsine (square $\operatorname{root}(\mathrm{x})$ ) function for the same purposes. Several standard methods are available to test whether the used transformation is adequate ${ }^{55}$ (Proc Univariate) and the correlation between sample means and SDs can be evaluated by Pearson and Spearman correlation coefficients and Levene's test of equality of variances. ${ }^{56}$

Appropriate adjustment for abstinence period needs careful consideration. Sperm count, volume, and concentration increase when the number of days with sexual continence increase from zero to seven but beyond this point additional increase is unlikely. ${ }^{25}$ Within the interval zero to seven days the relation is not linear but is probably better described by a logarithmic relation and finally the increment is dependent on the person's level of testicular function-men with a high daily sperm output have a higher increase of sperm count per day of abstinence than have men with a low sperm output. If the distributions of abstinence periods are identical in exposed and unexposed men in before and follow up samples there is no need for adjustment. However, if adjustment is needed it may either be done by adding a term - the logarithm of abstinence period - to the multivariate model or by adjusting all values to a fixed abstinence period of - for instance, three days. The correction factor might be derived from the actual data or from the literature-for instance $10 \mathrm{million} / \mathrm{ml} / \mathrm{day} .{ }^{25} \mathrm{~A}$ sensible strategy of analysis would be to test whether results are robust to both methods of adjusting for abstinence period.

\section{Conclusion}

In conclusion, andrological methods and epidemiological designs are available for the implementation of valid studies concerned with environmental impact on human testicular function. The cost and difficulty of the logistics of the study indicate that sperm studies should probably not be the first choice when the objective is initial screening of environmental impact on fertility. Simple questionnaire based techniques measuring time to pregnancy is a much less costly and a more feasible alternative in these situations. Occupational sperm studies, however, should be implemented when their is a need to corroborate or refute earlier evidence that specific exposures have impact on testicular function.

\section{Appendix: Asclepios}

Asclepios is an EU Biomedical Concerted Action Research Project on Occupational Hazards to Male Reproductive Capability running in 14 European Centres, coordinated by The Steno Institute of Public Health, University of Aarhus, Denmark:

Coordinator: G Danscher; Project management group: JP Bonde (chairman), $M$ Joffe (applicant holder), L Bisanti, A Giwercman, M Vanhoorne, P Thonneau, G Zielhuis.

- Belgium, Gent (P Kiss, M Vanhoorne) Denmark, Aarhus (A Abell, S Brixen Larsen, JP Bonde, G Danscher, E Ernst, H Kolstad); Copenhagen (A Giwercman, NE Skakkebæk) - England, London (M Joffe) - Finland, Helsinki ( $M$ Lindbohm, H Taskinen, M Sallmen); Turku (J Lähdetie) - France, Paris (A Clavert, P Thonneau) - Germany, Erlangen (KH Schaller, W Zschiesche) - Italy, Brescia (P Apostoli); Milano (L Bisanti); Pietrasanta (G Angotzi, L Lastrucci); Rome (M Spanò) - Netherlands, Nijmegen (H Thuis, GA Zielhuis); Rijswijk (W de Kort); Wageningen (D Heederik) Poland, Lodz (B Baranski)

1 Skakkebaek NE, Giwercman A, de Kretser D. Pathogenesis and management of male infertility. Lancet 1994;343: $147-9$.

2 Bonde JP, Giwercman A. Occupational hazards to male fecundity. Reproductive Medicine Reviews 1995;4:59-73.

3 Mattison DR, Thomford PJ. Selection of animals for reproductive toxicology studies: an evaluation of selected assumptions in reproductive toxicity testing and risk assumptions in reproductive toxicity testing and risk
assessment. In: Roloff $M V$, Wilson AGE, Ribelin WE, Ridley WP, Ruecker FA, eds. Human risk assessmentThe role of animal selection and extrapolation. London Taylor and Francis, 1987:195-213.

4 Sharpe RM. Regulation of spermatogenesis. In: Knobil E Neill JD, eds. The physiology of reproduction. New York: Raven Press, 1994:1-72.

5 Levine RJ, Symons MJ, Balogh SA, Arndt DM, Kaswandik NT, Gentile JW. A method for monitoring the fertility of workers: 1 Method and pilot studies. $f$ Occup Med 1980;22:781-91.

6 Levine RJ, Symons MJ, Balogh SA, Milby TH, Whorton $\mathrm{MD}$. A method for monitoring the fertility of workers. 2 Validation of the method among workers exposed to dibromochloropropane. F Occup Med 1981;23:183-8

7 Joffe $\mathbf{M}$. Time to pregnancy: a measure of reproductive function in either sex. Occup Environ Med 1996; (in press).

8 Lipshultz LI, Howards SS. Infertility in the male. St Louis Mosby Year Book, 1991:3-468.

9 Negro-Vilar A. Stress and other environmental factors affecting fertility in men and women: overview. Environ Health Perspect 1993;101(suppl 2):59-64.

10 Mittwoch U. Sex determination and sex reversal: genotype phenotype, dogma, and semantics. Hum Genet 1992;89: 467-79.

11 Sharpe RM, Skakkebk NE. Are oestrogens involved in falling sperm counts and disorders of the male reproductive tract? Lancet 1993;341:1392-5.

12 Bahamondes L, Alma FA, Faundes A, Vera S. Score prognosis for the infertile couple based on historical factors nosis for the infertile couple based on historical factors

13 Wichmann L, Isola J, Tuohimaa P. Prognostic variables in predicting pregnancy. A prospective follow up study of 907 couples with an infertility problem. Hum Reprod 1994;9:1102-8. 
14 Arumugam K, Omar SZ. The use of the semen analysis in predicting fertility outcome. Aust $N Z \mathcal{F}$ Obstet Gynaecol 1992;32:154-7.

15 Naghma-E-Rehan, Sobrero AJ, Fertig JW. The semen of fertile men: statistical analysis of 1300 men. Fertil Steril 1975;26:492-502.

16 Paston MJ, Sarkar J, Oates RP, Badway SZ. Computer aided semen analysis variables as predictors of male fertility potential. Arch Androl 1994;33:93-9.

17 Irvine DS, Macleod IC, Templeton AA, Masterton A, Taylor A. A prospective clinical study of the relationship between computer-assisted assessment of human semen quality and the achievement of pregnancy in vivo. Hum quality and the achievem
Reprod 1994;9:2324-34.

18 Macleod IC, Irvine DS. The predictive value of computerassisted semen analysis in the context of donor insemination program. Hum Reprod 1995;10:580-6.

19 Levine RJ, Mathew RM, Brown MH, Hurtt ME, Bentley KS, Mohr KL, Working PK. Computer-assisted semen analysis: results vary across technicians who prepare videotapes. Fertil Steril 1989;52:673-7.

20 Levine RJ, Mathew RM, Chenault CB, Brown MH, Hurtt $\mathrm{ME}$, Bentley KS, et al. Differences in the quality of semen in outdoor workers during summer and winter. $N$ Engl F Med 1990;323:12-6.

21 Rowe PJ, Comhaire FH, Hargreave TB, Mellows HJ. WHO manual for the standardized investigation and diagnosis of the infertile couple. Cambridge: Cambridge University Press, 1993.

22 Cooper TG, Neuwinger J, Bahrs S, Nieschlag E. Internal quality control of semen analysis. Fertil Steril 1992; 58:172-8.

23 Neuwinger J, Behre HM, Nieschlag E. External quality control in the andrology laboratory: an experimental multicenter trial. Fertil Steril 1990;54:308-14.

24 Kruger TF, Menkveld R, Stander FSH, Lombard CJ, Van der Merwe JP, Van Zyl JA, Smith K. Sperm morphologic deatures as a prognostic factor in in vitro fertilization. features as a prognostic factor
Fertil Steril 1986;46:1118-23.

25 Schwartz D, Laplanche A, Jouannet P, David G. Withinsubject variability of human semen in regard to sperm count, volume and number of spermatozoa and length of abstinence. $\mathcal{F}$ Reprod Fertil 1979;57:391-5.

26 Makler A, Zaidise I, Paldi E, Brandes JM. Factors affecting sperm motility. I. In vitro change in motility with time after ejaculation. Fertil Steril 1979;31:147-54.

27 Rosenberg MJ, Wyrobek AJ, Ratcliffe J, Gordon LA, Watchmaker G, Fox SH, et al. Sperm as an indicator of reproductive risk among petroleum refinery workers. $\mathrm{Br} \mathcal{F}$ reproductive risk among
Ind Med 1985;42:123-7.

28 Ratcliffe J, Schrader SM, Steenland K, Clapp DE, Turner $\mathrm{T}$, Hornung RW. Semen quality in papaya workers with long term exposure to ethylene dibromide. $\mathrm{Br} \mathcal{F}$ Ind $\mathrm{Med}$ 1987;44:317-26.

29 Welch L, Schrader S, Turner T, Cullen M. Effects of exposure to ethylene glycol ethers on shipyard painters. II Male reproduction. Am f Ind Med 1988;14:509-26.

30 Ratcliffe JM, Schrader SM, Clapp DE, Halperin WE, Turner TW, Hornung RW. Semen quality in workers exposed to 2-ethoxyethanol. BrF Ind Med 1989;46:399-406.

31 Bonde JP. Semen quality and sexual hormones among mild steel and stainless steel welders: a cross sectional study. steel and stainless steel welders:

32 Figa-Talamanca I, Dell'Orco V, Pupi A, Dondero F, Gandini L, Lenzi A, et al. Fertility and semen quality of workers exposed to high temperatures in the ceramics industry. Reprod Toxicol 1992;6:517-23.

33 Van Hoorne M, Comhaire F, De Bacquer D. Epi- demiological study of the effects of carbon disulfide on male sexuality and reproduction. Arch Environ Health 1994;49:273-8.

34 Bonde JP. Semen quality and sex hormones among mild steel and stainless steel welders: a cross sectional study. $B r \mathcal{F}$ Ind Med 1990;47:508-14.

35 Schrader SM, Ratcliffe JM, Turner TW, Hornung RW. The use of new field methods of semen analysis in the study of occupational hazards to reproduction: the example of ethylene dibromide. $F$ Occup Med 1987;29: 963-344.

36 Schrader SM, Turner TW, Breitenstein MJ, Simon SD. Longitudinal study of semen quality of unexposed work-
ers. I Study overview. Reprod Toxicol 1988;2:183-90.

37 Schrader SM, Chapin RE, Clegg ED, Davis RO, Fourcroy JL, Katz DF, et al. Laboratory methods for assessing JL, Katz DF, et al. Laboratory methods for assessing human semen in epidemiologic st

38 Macleod J. Semen quality in one thousand of known fertility and in eight hundred cases of infertile marriage. Ferti Steril 1951;2:115-39.

39 Rehan N. Semen characteristics of fertile Pakistani men Fournal of the Pakistan Medical Association 1994;44: $62-4$.

40 Macleod J, Wang Y. Male fertility potential in terms of semen quality: a review of the past, a study of the present. semen quality: a review of the
Fertil Steril 1979;31:103-16.

41 Meistrich ML. Effects of chemotherapy and radiotherapy on spermatogenesis. Eur Urol 1993;23:136-42.

42 Bonde JP. Semen quality among welders exposed to radiant heat. Br F Ind Med 1992;49:5-10.

43 Bonde JP. Semen quality in welders before and after three weeks of non-exposure. Br F Ind Med 1990;47:515-8

44 Levine RJ, Brown MH, Bell M, Shue F, Greenberg GN Bordson BL. Air-conditioned environments do not prevent deterioration of human semen quality during the summer. Fertil Steril 1992;57:1075-83.

45 Amann RP. A critical review of methods for evaluation of spermatogenesis from seminal characteristics. F Androl spermatogenesis
$1981 ; 2: 37-58$

46 Sharpe RM. Monitoring of spermatogenesis in man-measurement of Sertoli cell- or germ cell-secreted proteins in semen or blood. Int $\mathcal{F}$ Androl 1992;15:201-10.

47 Van Hoorne $M$, Vermeulen A, De Bacquer D Epidemiological study of endocrinological effects of car bon disulfide. Arch Environ Health 1993;48:370-5.

48 Gustafson $\AA$, Hedner P, Schutz A, Skerfving S. Occupational lead exposure and pituitary function. Int Arch Occup Environ Health 1989;61:277-81.

49 Johnson L, Petty CS, Neaves WB. Influence of age on sperm production and testicular weights in men. $f$ Reprod Fertil 1984;70:211-8.

50 Vine MF, Margolin BH, Morrison HI, Hulka BS. Cigarette smoking and sperm density: a meta-analysis. Fertil Steri smoking and sperm

51 Gluud C. Testosterone and alcoholic cirrhosis. Copenhagen: Lgeforeningens forlag, 1988

52 Procope BJ. Effect of repeated increase of body temperature on human sperm cells. Int $\mathcal{F}$ Fertil 1965;10:333-9.

53 Pocock SJ. Clinical trials: practical approach. New York John Wiley, 1983.

54 Schenker MB, Samuels SJ, Perkins C, Lewis EL, Katz DF Overstreet JW. Prospective surveillance of semen quality in the workplace. F Occup Med 1988;30:336-44.

55 SAS Institute. SAS user's guide: statistics, version 5. Cary, NC: SAS Institute, 1986 .

56 Snedecor GW, Cochran WG. Statistical methods, 7th ed. Ames, Iowa: The Iowa State University Press, 1980:253. 